\title{
Pastoral Ministry from the Margins: Pastors' Wives in Apostolic Faith Mission in Zimbabwe
}

\author{
Nomatter Sande \\ https://orcid.org/0000-0002-4177-8391 \\ University of South Africa \\ pastornomsande@yahoo.com
}

\author{
Byron Maforo \\ https://orcid.org/0000-0003-1180-1180 \\ AFM Zimbabwe \\ pastormaforo@gmail.com
}

\section{Abstract}

This study researched pastors' wives from the Apostolic Faith Church Mission in Zimbabwe as a case study to understand gender-sensitive leadership models in African Pentecostal churches. Women are the majority in both Apostolic Faith Missions and all the churches, hence the focus of pastoral ministry on women. The pastors' wives' contributions to the pastoral ministry are hardly told, as effective ministry is accredited to male leadership. Pastors' wives are not "ordained to the ministry; they are regarded as helpers of their spouses who received a calling to ministry." In reality, pastors' wives bear enormous responsibility for the church by contributing financial and human resources to the ministry. Pastors' wives are not trained; hence, they employ "experiential theology" to meet the needs of their fellow women. The overarching aim of this study was to explore the contribution of pastors' wives to pastoral ministry in the African Pentecostal churches. The study used "pastoral ministry" as a conceptual framework. The study employed a qualitative methodology, and data were gathered through in-depth interviews. The study concludes that pastors' wives' pastoral ministry is a useful tool for church growth and should not operate from the margins.

Keywords: pastors' wives; experiential theology; pastoral ministry; Apostolic Faith Mission Church of Zimbabwe

\section{UNISA $\cong$}




\section{Introduction}

The Apostolic Faith Mission (AFM) in Zimbabwe traces her roots from the 1908 Azusa Street Revival in the United States. According to Sande and Denga $(2019,267)$, "the Apostolic Faith Mission (AFM) is a classical Pentecostal church and is the mother of Pentecostal churches in Zimbabwe." Currently, the AFM is going through "irreconcilable differences and disagreements over the amendments of the Constitution" (Mupangwa and Chirongoma 2020,1). Around 2018, the AFM membership was around two million (Chivasa 2017, 1). Of these two million members, women are the majority (Sande 2017a, 51). In spite of this reality, women are not the majority in church leadership. Women's struggle to climb the church leadership ladder is not unique to the AFM. Mujinga (2020) notes the same challenges in his research on the Methodist Church in Zimbabwe. The setback is not only about providing space for women within the church, but even the few who finally make it to influential leadership roles, are hardly acknowledged. According to Sande $(2019,185)$ there is an "increase in gender studies that has brought insightful information about the plight of women in different societies. The patriarchal system is responsible for increasing women injustices. Somewhat, Pentecostalism is among the drivers of the status quo." Given the patriarchal tendency of both the church and society, in general, women go through more difficult situations than their male counterparts do. In Zimbabwe and in many parts of southern Africa, the church is still a strong and revered institution. The church continues to be the primary place where economic, social, psychological and spiritual needs of the people are met. From a leadership perspective, the question to ask is: Who carries the burden of the believers in an African Pentecostal church? Since women are the majority of the church, pastors' wives encourage congregants to deal with their challenges, thus, the pastors' wives contribute effectively to pastoral ministry. Writing from the AFM of South Africa, Kgatle (2019, 5-6) states that "the AFM church should look at its patriarchal structure as a sin, confess it and subsequently discard it - as a result, they should be able to accept women's humanity as they are placed in their rightful positions of leadership." This applies to the church in Zimbabwe because the AFM of South Africa is the mother church. If Kgatle's statement is anything to go by, then the confession of the patriarchal sin should start from the pastors who are responsible for church ministry. The patriarchal domination, doctrines and church liturgy push the pastors' wives' pastoral ministry to operate from the margins. Therefore, the overarching aim of this study is to explore the contributions of pastors' wives to pastoral ministry in the AFM.

\section{Conceptual Framework: Pastoral Ministry}

The study uses pastoral ministry as a conceptual framework to understand the contribution of pastors' wives to pastoral ministry in the AFM. Pastoral ministry is a product of both pastoral theology and practical theology. According to Ganzevoort and Roeland $(2014,91)$, pastoral theology is closely related to practical theology. In this study, pastoral ministry is justified because it brings the dimension of pastoral care to 
the study. Caring for women in Africa calls for understanding the socio-cultural, indigenous and traditional religions. While pastoral ministry is a broad practice area, this study focuses on how pastors' wives engage in pastoral care and the practice of preaching in the African Pentecostal churches. According to Doehring (2015, xxii), pastoral care is the practice of church leaders in dealing with challenges confronting believers in the church. From an academic perspective, McNeil developed the term "pastoral care" from the concept of "curing soul" around 1977, which later was adopted as a focal point in Christian history (Lartey 2003, 21). Therefore, pastoral ministry is anchored on how the minister relates to God first and second, to the flock. The approach used by pastors' wives in ministry is from the margins, developing what we are calling an "experiential theology." In this study, "experiential theology" is used to express one's relationship with God and how one encounters life challenges to meet the needs of others without theological training. Experiential theology can be viewed as an offshoot of feminist pastoral theology. According to Moore (2002, 19), "feminist pastoral theology starts with practice, not with theory; is mutual, not paternalistic or clerical; is gender-sensitive and eschews sexism; is political and structural, not individualistic; is pluralistic and dialogical, not authoritarian." Thus, analysing the contributions of pastors' wives in the context of pastoral ministry will not only illuminate the patriarchal tendencies in the church, but expose the notion that the nature of women tends to promote the growth of the church by exhibiting their caring nature, which fits in well with pastoral practice. Engaging the experiences of pastors' wives in ministry helps to understand pastoral ministry from the margins. As put by Moore $(2002,19)$, "feministic pastoral theology is an advocacy theology, but also values critical reflection."

\section{The Method}

The study that directed this article used purposive sampling to select the pastors' wives as respondents. The sample size for the study was 48 pastors' wives. The study focused on the pastors' wives ministering in urban, peri-urban and farm areas. These pastors' wives lead assemblies ${ }^{1}$ with membership ranging from 40 women to 500 women per assembly. Selecting the pastors' wives was not difficult because the researchers are ordained pastors within the AFM church. The study was conducted during the Coronavirus (COVID-19) lockdown period. The researchers interviewed 18 pastors' wives via telephone. This method was effective to reach out to the pastors' wives ministering in farms and rural areas. The AFM church has a WhatsApp platform for pastors and their spouses. Therefore, the researchers used this database to select the pastors' wives from different locations. Through individual communication, the researchers asked questions through WhatsApp chats and the pastors' wives responded. The respondents' data were gathered and transcribed. The overarching aim of this study was to explore the contribution of pastors' wives to pastoral ministry in the African

1 In AFM an "assembly" is a gathering of the members, interchangeably known as the "church." 
Pentecostal churches. In order to achieve this goal, this study asked the following questions:

- What are the pastors' wives' roles in the Apostolic Faith Mission?

- What are the challenges that pastors' wives encounter during the execution of their duties?

- What theological tools do the pastors' wives use to meet the needs of women congregants?

- What help do pastors' wives need to be more effective in their pastoral ministry?

We fulfilled ethical considerations by obtaining consent from the church. Participants were asked for consent and researchers explained that participants could withdraw from the study at any time they chose to do so.

\section{Findings}

\section{Roles of Pastors' Wives}

When asked about the role of the pastors' wives in the church, 20 out of 30 respondents were quick to talk about their china chemadzimai (Thursday meetings for women). About three-quarters of the respondents added that depending on the local church programme, Monday prayer meetings helped to activate china chemadzimai. These prayers were carried out at cell level (a cell is a home group meeting) during the day and Tuesday women's prayer meetings were done at church. Apart from china chemadzimai, which is explicitly stated in the AFM Constitution, pastors' wives are also responsible for girls' fellowship meetings. Girls' fellowship meetings are platforms for pastors' wives to mentor, teach and counsel girls on various issues. These are also platforms which prepare girls for womanhood. Less than a quarter of the pastors' wives reported that the "youth department leads the girls' fellowship." The pastor's wife oversees widows and single mothers and she organises programmes for them. The striking result to emerge from the data is that pastors' wives operate as chairpersons of the women's department and they conduct committee meetings and assist members of the women's committee in the execution of their duties. The pastors' wives report to the "pastor" who is the overall chair of all committees at the church.

Half of the respondents felt that they did more work than the pastors do. For instance, one respondent said, "pastors' wives do more work in ministry, which includes partnering with the pastor, giving spiritual support to the pastor and praying for the burdened women." It was mentioned that the pastors' wives were the pastor's closest prayer partner, teaching the word and living an exemplary Christian life. It was also suggested that the success or failure of a pastoral ministry in the church is determined by the capabilities of a pastor's wife. However, one respondent suggested that all pastors who fail in their ministry, did so because of the pastors' wives. 
Pastors' wives act as confidants and assist in the work of the pastor, especially in counselling girls, single and married women as well as widows. Further explanation was that the presence of the pastors' wives in counselling sessions was meant to provide specific knowledge to challenges that women face. In addition, "they protect their husbands in case some women may be having ulterior motives to tempt the men of God into sin and adultery," explained an elderly respondent. Pastors' wives either accompany pastors or conduct house visitations, hospital visitations and follow-ups of new female believers on their own.

When asked about how pastors view their participation in ministerial church doctrines, the respondents reported that pastors' wives help to serve the sacraments of the church. It was explained that for the Holy Communion sacrament, the pastors' wives clean the utensils. Further, they put decorations on the tables where the pastors will administer the sacrament. One respondent said: "We pastors' wives do most of the work in the Holy Communion, which includes preparations and keeping the utensils used for serving the Holy Communion. Our husbands are just there for the ritual in the church and later leave everything else to us." In addition, during water baptism, the pastors' wives use clothes to cover women's bodies when they come out of the baptismal pool. The same goes for the assistance they offer to mothers during the dedication of babies. It was the pastors' wives who helped women to pray for their children so that God could protect them.

Pastors' wives are central players during church rituals and rites of passages. During weddings, the pastor's wife is a key person in the whole process. The pastor's wife, together with elderly and experienced women (which she recommends), organises a kitchen party for the bride. This party is a learning and preparatory platform for the bride, where she is taught about her imminent roles as a wife and mother. The dressing of the bride and other ecclesiastical examinations are done under the supervision of the pastor's wife, who gives a recommendation on the sanctity of the bride to the pastor. During the wedding, the pastor's wife plays a motherly role towards the wedding couple.

Pastors' wives are key players at funerals and childbirth rituals. At a funeral, pastors' wives play a closer role to the bereaved. For instance, they comfort, console and spend more time with the bereaved women. Interestingly, three-quarters of the respondents reported that they sleep at funerals and spend more days visiting the bereaved. When a new child is born, the pastors' wives are the first to know. They visit women in labour facilities and update the pastor on the progress and need for prayers. After the child is born, the pastors' wives act as healthcare givers by assessing the needs of mother and child. In cases where there are inadequacies, the pastor's wife mobilises resources from the fellow women in the church to assist the family of the baby. 


\section{Pastors' Wives' Challenges}

What are the challenges pastors' wives encounter during the execution of their duties? All 30 respondents explained that they dealt with the diverse challenges that women face. Over three-quarters of the respondents linked the challenges they faced to the hardship caused by the decline in the economic and political situation in Zimbabwe. A common view amongst the respondents was that economic hardship was affecting women, making some to resort to informal survival businesses such as vending, while others were lured into extra-marital affairs. For instance, widows and some single mothers were choosing to live with partners before the expected church wedding. Informal businesses affected the attendance of women to meetings, as they would be working in order to feed their families. Another finding showed that pastors' wives deal with the social life of the community. This was echoed by one pastor's wife who revealed " $\ldots$ as a pastor's wife I am viewed as the mother of the local church. My motherly role extends to the community. When the community looks at me, they see amai vemusha (mother of the home). As amai vemusha, together with other women in the church, we must address certain charitable needs of the community."

A recurrent theme in the study was a sense amongst respondents that pastors' wives do not get the honour they deserve as co-workers with their husbands in ministry. One respondent stated that "some women in the church look down upon the pastors' wives, acting as if they can offer better service to the church than them." This issue emanated mostly from fellow women's committee leadership who sometimes felt that they were older and more experienced in running church business than the pastor's wife. Mostly young pastors' wives are belittled because of age and are disobeyed at the expense of proper ministerial service. This attitude cascades to other women who will divert their loyalty from the pastor's wife to ordinary women leaders. Some respondents expressed the belief that insubordination of women is rampant and it is caused by some women feeling that they were superior to pastors' wives.

Almost two-thirds of the respondents said that some women blame the pastors' wives for poor time management and lack of financial resources. On the other hand, some pastors' wives felt that they walked long distances for ministry and worked with incompetent leaders. Due to lack of proper financial support, tasks such as visits and charity work by pastors' wives were affected. Just over three-quarters of the respondents asked why the church did not remunerate pastors' wives for the work they did. For instance, one respondent stated, "we do full-time work in the ministry and the appreciation we receive does not reflect the work we do."

Moreover, another participant commented that the church does not remunerate the pastors' wives and in their voluntary service, they are expected to take good care of their children. On the same note, the pastors' wives bemoan poor remuneration of their husbands by the church as a challenge to their families, thereby affecting the proper execution of duties. Consequently, contributing further on this issue, a respondent said 
that the church failed to declare openly that pastors' wives were also called to the ministry in the same manner as their husbands.

\section{Experiential Theology}

When asked what theological tools the pastors' wives use to meet the needs of women, 25 respondents alluded to the notion of using "prayer" as a tool for ministry. For example, one respondent said that "praying together as women bind women as a united force"; therefore, pastors' wives ensured the primacy of prayer was cultivated in all women's activities. One respondent commented that the most important teachings for women were to encourage women to live a Christian, morally upright life which does not affect the image of the church but cultivates good relationships among women and the entire church leadership. Approximately half of the respondents commented that though they did not attend theological training, the Holy Spirit helps them to teach about areas concerning the livelihoods of women. As put by one respondent, "I just go to the Bible and look for aspects about marriage, children, business, and women's roles in the community, family and church, legal conversations among others; I have seen people get blessed."

Suggestions from other respondents were that the best way to preach a sermon that impacts the lives of women is to use your experience and examples of what is happening in society. Another issue that was identified was that pastors' wives generate what to teach and preach from the women themselves. Women use platforms to gather and encourage each other to venture into entrepreneurship and do income-generating projects to alleviate poverty in families. In addition, they carry out girls' fellowships and engage in counselling on issues that affect the girl child. The same counselling was offered to widows and single mothers. These programmes motivated and encouraged women to enjoy their church membership.

All the respondents in this study explained that women were responsible for raising funds for the church, and this work was mostly spearheaded and encouraged by the pastors' wives. Further, the pastors' wives motivated women to raise funds for charity, which extends to support the needy in society, orphanages and the elderly in old people's homes. All these programmes are achieved through inviting fellow pastors' wives as guest speakers. Accordingly, taken together, these results provide valuable insights into the notion that pastors' wives use various methods, experience and events of life to meet the needs of women in the church. From several sermons that the researchers listened to, most pastors' wives were testifying how women appreciate their ministry. For example, in one service, one woman testified, "we do what we do in church because our mother taught us how to work for God."

\section{Beyond Today into the Future}

When asked what help do pastors' wives need to be more effective in their pastoral ministry, some respondents mentioned that the church should provide financial support 
for the pastors' wives' ministry. Such a programme would help to motivate these women leaders for active service in the church. All the respondents mentioned that there was a need for leadership training and ordination of pastors' wives. The need for training was dire, as explained by one respondent, saying: "I was married by a pastor and before I knew it, I was supposed to lead a group of elderly women who were as good as my mothers and grandmothers. I had no orientation and no experience; I simply had to find my way as a leader." One notable suggestion on training was that the pastors' wives' training could be developed in such a manner that it deals with underlying issues and ministration that targets women, children, orphans and entrepreneurship. However, others felt that the church must train all pastors' wives the same way they do pastors. In addition, other respondents felt that the church ought to introduce short modular courses for pastors' wives and follow up with refresher courses periodically.

It was also widely reported that the church must build a professional work ethic in pastors' wives' pastoral ministry to control conflicts. Open, constructive dialogue between pastors and pastors' wives could help to bring out the ministry of pastors' wives from the margins. Appraisals and intentional development of pastors' wives could help to grow the church. An interesting suggestion was that other pastors are immature and fail to execute their ministries effectively, thus trained pastors' wives could help to cover this gap and advance the pastoral ministry in this context. It was also suggested that the church should recognise the pastors' wives as key in the ministry, in the same manner as their husbands, and allow them to carry out their duties freely.

\section{Discussion of Findings}

The findings of this study indicate that the pastors' wives have diverse roles within the church. The primary focus of the pastors' wives is ministering to the women. Pastoral ministry to women is like ministering to the whole church because women are the majority of the church members. Nevertheless, while accepting the church's women's department, the problem is that some of the roles are blindly handed down through tradition. Africans have an affinity to follow oral traditions, even if they are outdated. According to Duncan and Hunt $(2006,99)$, the women's ministry represents the entire life and work of the church. There is a case here to argue that pastors' wives have an overarching responsibility for the growth and stability of the church. While this may be true, the pastors' wives' pastoral ministry functions from the margins.

However, as already acknowledged that pastors' wives' ministerial duties focus on empowering women, there are patriarchal tendencies in the church. It seems that the pastors' wives have nothing worth to offer to men and boys in the church. According to Sande (2017b, 60), "the challenge that hinders gender equality in leadership positions in AFM lies in the traditional belief that women should not teach in the church." Without getting embroiled in the redaction criticism about women's positions and the Bible, it is worth highlighting that the role of women in the church is mirrored within the Shona culture in Zimbabwe. This is what sustains patriarchy in the church. Women are not 
expected to lead men in the public arena, but should talk to their husbands at home. Such an attitude is indirectly sustained in the church.

In cases where the church seems to embrace women in leadership, the reality is that these are not influential positions. For instance, the findings of this study showed that pastors' wives participate in church sacraments. However, in both holy communion and water baptism, pastors' wives do the preparation work but do not perform the actual sacrament. Sacraments are efficacious signs of the divine promise which conveys invisible grace through visible signs; and these have a profound theological significance in the church (Thiselton 2015, 360). It is highly unlikely that the church, by allowing the pastors' wives to help in keeping and preparing the utensils for the sacraments, suggests that they are equal ministers. This point goes a long way to support the notion that pastors' wives' pastoral ministry is from the margins. We argue, therefore, that since the pastors' wives participate in keeping and preparing the sacrament's utensils, they help indirectly to minister salvation to the church and the church should embrace it. According to Erickson $(2001,1008)$, sacraments are a means that transmit and enable receiving of salvation in the church. It is possible, therefore, that the core function of the pastors' wives' pastoral ministry is to help the church focus on issues of salvation.

Further findings of this study indicate that all pastors' wives feel that they are there to support their husbands. In addition, the Apostolic Faith Mission of Zimbabwe's tradition mentions that pastors' wives are not called, but they are there to support their husbands. Should pastors' wives feel that they want to be treated on par with their husbands; the church categorically states that one should display evidence of calling upon their lives and go for training at a theological seminary. Perhaps, Duncan and Hunt $(2006,32)$ were correct when they explicated that women's ministry in the evangelical (Pentecostal) setting is both complementary and collaborative. While the complementary and collaborative are useful tools in the pastoral ministry, the challenge is that some pastors' wives are victims of the stressors that target their husbands. As put by Muguti and Sande $(2019,191)$, "Christian marriage institutions present not only the body of a woman but the status and resources as belonging to the husband." It is possible that some pastors' wives endure the ministry not because they are willing, but to please their husbands to whom they feel obligated to support in ministry.

The findings of this study showed that pastors' wives encounter unprecedented challenges about the issues of women. Besides personal spiritual issues, the respondents mentioned that most issues of women emanate from the economic and political factors in Zimbabwe. Therefore, the pastors' wives influence the church through their ministerial capabilities. Since the church has more women than men, the pastors' wives play a leading motherly role in the church. It is crucial to keep in mind that African Pentecostal churches have both points of continuity and discontinuity with the indigenous culture; there are things found in the indigenous culture that continue to be practised in the church. According to Anderson (2018, 3), to understand African Pentecostal churches, there is need to accept the notion of the Spirit in a spiritual world 
and embrace that the African religious and cultural practices reappear in African Pentecostalism. Therefore, within the African set-up, the church resembles the communal family. From the grassroots levels, the family set-up portrays an extraordinary view of women leadership, to the extent that "the Shona people's proverb in Zimbabwe musha mukadzi [the woman makes a house a home] is an admission that what sustains every family is a woman" (Sande 2017b, 56). Therefore, to relegate the pastors' wives' pastoral ministry to the margins, is an ecclesiastical misnomer.

Another finding showed that pastors' wives go beyond dealing with the social challenges of the believers, but they are viewed as amai vemusha (mother of the home). The community and compassion work of pastors' wives capsulise the charitable ministry of a woman. The helping "nature" in a woman equips pastors" wives and draws them to a practical dimension of charity work (Duncan and Hunt 2006, 30). Pastors' wives as mothers, ought to stand with women in the church and address the needs of the community, including charity works. The reason that pastors' wives are viewed as "mothers" in the church, is that their homes are considered as open for every member of the congregation. Both pastors' wives and pastors favour the practice of self-denial and working for God.

Nevertheless, pastors' wives must think about self-care when it comes to dealing with pastoral ministry. This aligns with Ziguras $(2004,3)$, who defines self-care as "the active process of recovering, maintaining and improving one's health." Further, whether in the presence of the pastor or not, this study showed that pastors' wives face challenges of women needing counselling. To this, Zagano (2012) shares the sentiment that the service of women in the church needs to be nurtured and appreciated. The growth of the African Pentecostal churches is based on the ability of the leaders to offer holistic solutions to the problems of the believers.

Blame, insults and words of discouragement are some of the challenges that pastors' wives face in pastoral ministry. Although this study did not explore the psychological effects of pastoral ministry upon the pastors' wives, according to Samushonga (2020, 1), "the risk of burnout in pastoral ministry is more than a myth!" Pastoral ministry places a high demand on the leaders; as such, pastors' wives are at the risk of being trapped by notions of failing to fulfil the needs of women, their husbands and children. Thus, the pastors' wives are more prone to issues of burnout than their husbands because they find solace in the notion that God called them to ministry and the Spirit of God replenishes them. We acknowledge that some abuses that pastors' wives experience are money-related. Regarding money, some pastors' wives are abused because women feel that stipends (salaries) of their husbands come from their tithes and offerings.

The research also established that the pastors' wives lead a larger population of the church and they use the theology from below, which draws from their experiences and applies them to what will be happening in the lives of the people. On the contrary, the ecclesiological tradition, which emphasises that "men provide leadership and women 
offer support" is a misnomer in the essence of ministry (Grenz and Kjesbo 1995, 25, 210). It is likely that an African Pentecostal church is strengthened more by women's ministry led by the pastor's wife because women tend to be passionate about caring for people. In a similar study, Sande (2017b, 55-56) states that "there is an adage that 'women are enemies to themselves'; in fact, female leaders look down upon themselves, and it consequently filters down to those they lead." Regardless of this theology from below, pastors' wives continue to impact women to have divine solutions to their challenges. These capabilities include how the pastor's wife builds relationships among women in the church, how she leads the women's department, and her relationship with the leadership of the church, among others. The women's ministry has an abundant discipleship component which cements godly relationships. These godly relationships enable empowerment among women, thereby strengthening church membership (Duncan and Hunt 2006, 31).

In addition, the study showed that when preaching or teaching, some pastors' wives observe the challenges of women in the church and use scriptures to give direction to the women. This finding is contrary to principles of preaching as explained by Bavinck $(2011,505)$, who states that the preacher ought to be theologically versatile, discovering the ideas that are concealed in the scriptures and explicating the meaning to the church. African Pentecostals are not much interested in the accuracy of the scripture, but more in the Spirit of the scripture (Sande and Samushonga 2020, 5-6). According to Sande (2017a, 52), "on average, an African is not a reader of the Bible or research on theological issues; most people in Zimbabwe rely on the preacher for their religious claims." The findings in this study showed that there are testimonies where God uses the pastors' wives. African Pentecostal churches believe in the spirit world, which affects every facet of the believer (Anderson 2018, 213).

Another finding showed that the pastors' wives use their life experiences to impact and influence women in the church. Such a tool is "experiential theology," which testifies the personal walk with God rather than other people's experience as mirrored in the scriptures. Perhaps, it is such an approach which makes women in the church practise what the pastors' wives teach them and view them as their "mother." Such experiential theology encourages women to contribute to financial resources, support church projects and participate in evangelism and missions. The problem of this theology is that it makes the pastors' wives feel that they can do everything and solve any problem. Pastors' wives must learn not to carry all the baggage of the believers. Nowadays, there are other institutions that can assist in equipping the believers. According to Sande $(2019,2)$, "pastoral ministry is broader than pastoral care and means "church or parish"" ministry.

The study revealed suggestions by pastors' wives for moving beyond today into the future by receiving appropriate theological training that helps them to do pastoral ministry effectively. According to Grenz and Kjesbo $(1995,37,71)$, the gospel of Jesus liberated and granted women the opportunity to participate fully in the community of 
faith. Women became practical agents of charity work, influencers of equality, and they influenced the control of public life throughout Christian historical developments. The message of Jesus coming in the form of the gospel, consciously attempts to liberate women from patriarchal enslavement. Men used to view themselves as superior and better propagators of religious faith. However, through the work of Jesus, women attained equal status with men. Even if there are scriptures which support the women's leadership role, in the AFM, there is a need for a "deeper systematic transformation, lest we change the actors and not the script" (Sande 2017b, 56).

The study demonstrated that there is a general expectation that the pastors' wives must know everything in the Bible. In this case, the church should not negate training pastors' wives so that they can influence women. In a similar line of thought, some pastors' wives put pressure on themselves in order to measure up with men. According to Sande (2017b, 56), "it seems that women believe that they must act like men in order to be seen as leaders. It is evident from the language they use when preaching; for example, 'handisi mukadzi kana ndamira pano ito ona murume'; 'I am not a woman when I stand here, see me as a man'." What this means is that pastors' wives should be allowed to follow their career and choose to have their own professions. Not everyone has the ability to preach and lead women.

The research also showed that pastors' wives do not receive remunerations for some of the sacrifices they make in pastoral ministry. According to Machingura and Chikwanha $(2019,231)$ "AFM pastors' wives are not salaried. Nevertheless, they are required and expected to spend most of their time doing church work alongside their husbands." As put by one respondent, "sometimes we walk long distances on foot doing house visitations or other women's ministry programmes. The church does not provide us with funds to use for ministry work." Lack of moral, material and social support negatively affects motivation in a church leader (Grenz and Kjesbo 1995, 214). Such sentiments show some painful experiences of pastors' wives. It is beneficial for the church to have a budget for pastors' wives to motivate them and support the work they do in the church. This resonates with findings by Duncan and Hunt $(2006,52)$, who argue that the functions of women's ministry require adequate financial resources. These resources must not be limited towards once-off events or tasks, but the resources must always be availed for any ministry work to be done. Thus, the provision of funds and other material needs would enhance the women's pastoral ministry. It can be demotivating for a leader to walk long distances in volunteering without pay to serve the church regularly.

\section{Conclusion}

The study contributes to the understanding that pastors' wives' pastoral ministry is the heartbeat of the growth of African Pentecostal churches. Their ministry should move from the margins and be recognised as central, because of the nature of the pastoral care they do. Through the pastoral ministry framework, this study showed that pastors' wives have the ability to do pastoral care, because of their nature as mothers. Pastors' wives 
have developed "experiential theology" in order to meet the needs of women in the church. Such theology from below is not attained from theological seminary training, but daily experiences which are applied to the lives of the people. Further, the study underlined that the patriarchal tendencies of the church fail to give theological support to personnel who are key players in ministry. On the downside, the pastors' wives are susceptible to burnout, ill-health and depression because of the challenges of pastoral ministry in the church.

\section{References}

Anderson, A. H. 2018. Spirit-filled World: Religious Dis/Continuity in African Pentecostalism. New York: Macmillan.

Bavinck, H. 2011. Reformed Dogmatics. Grand Rapids: Baker Academic.

Chivasa, N. 2017. "Instituting Dispute Resolution Procedures in the Apostolic Faith Mission in Zimbabwe Church.” In Die Skriflig (Online), 52 (1), 2018. https://doi.org/10.4102/ids.v52i1.2285.

Doehring, C. 2015. The Practice of Pastoral Care: A Postmodern Approach. Louisville. Kentucky: John Nox Press.

Duncan, L. J., and S. Hunt. 2006. Women's Ministry in the Local Church. Wheaton: Cross Way Books.

Erickson, M. 2001. Christian Theology. Grand Rapid MI: Baker.

Ganzevoort, R. R., and Johan H. Roeland. 2014. "Lived Religion. The Praxis of Practical Theology." International Journal of Practical Theology 18 (1): 91-101. https://doi.org/10.1515/ijpt-2014-0007.

Grenz, S. J., and D. M. Kjesbo. 1995. Women in the Church: A Biblical Theology of Women in Ministry. Downers Groove: Intervarsity Press.

Kgatle, M. S. 2019, "Gender Dimensions in Pentecostal Leadership: The Apostolic Faith Mission of South Africa as a Case Study." Verbum et Ecclesia 40 (1): 1-7. https://doi.org/10.4102/ve.v40i1.1980.

Lartey, E. Y. 2003. In Living Colour: An Intercultural Approach to Pastoral Care and Counselling. London: Jessica Kingsley Publishers.

Machingura, F., and N. Chikwanha. 2019. "The Bible and the Place of Widows in the Apostolic Faith Mission in Zimbabwe." In The Bible and Gender Troubles in Africa, edited by Joachim Kugler, Rosinah Gabaitse, Johanna Stibert, 217-236. Bamberg: Unversity of Bamberg Press, 
Moore, Z. B. 2002. Introducing Feminist Perspectives on Pastoral Theology. Sheffield: Sheffield Academic Press.

Muguti, M., and N. Sande. 2019. "Dealing with Women's Sexual Autonomy in Pentecostalism in Zimbabwe." In The Bible and Gender Troubles in Africa, edited by Joachim Kugler, Rosinah Gabaitse, Johanna Stibert, 185-201. Bamberg: Unversity of Bamberg Press.

Mujinga, M. 2020. Rising against all Odds: The Leadership Experiences of three Female Clergy in the Methodist Church in Zimbabwe. HTS Teologiese Studies/Theological Studies 76 (2): a5864. https://doi.org/10.4102/hts.v76i2.5864.

Mupangwa, T., and S. Chirongoma. 2020. "The Challenges of being a Female Pastor: A Case of the Apostolic Faith Mission in Zimbabwe." HTS Teologiese Studies/Theological Studies 76 (2): a5838. https://doi.org/10.4102/hts.v76i2.5838.

Samushonga, H. M. 2020. "Distinguishing between the Pastor and the Superhero: God on Burnout and Self-care.” Journal of Pastoral Theology, 1-17. https://doi.org/10.1080/10649867.2020.1748919.

Sande, N. 2017a. "The Impact of the Coalition of Pentecostalism and African Traditional Religion (ATR) Religious Artifacts in Zimbabwe: The Case of United Family International (UFI)." Journal for the Study of Religions of Africa and its Diaspora 3 (1): 46-59.

Sande, N. 2017b. "Faith and Equality: Rethinking Women in Leadership Positions in Pentecostalism." Journal of Gender and Religion in Africa 22 (2): 50-62.

Sande, N. 2019. "Pastoral Ministry and Persons with Disabilities: The Case of the Apostolic Faith Mission in Zimbabwe." African Journal of Disability 8 (0): 1-8, a431. https://doi.org/10.4102/ajod.v8i0.431.

Sande, N., and B. Denga. 2019. "Politics and Development in Zimbabwe: Political Voices from the Apostolic Faith Mission (AFM)." In Religion and Development in Southern Africa 2, edited by James N. Amanze, Maake Masango, Lilian Siwila, and Ezra Chitando, 267-277. Mzuzu: Mzuni Press. https://doi.org/10.2307/j.ctvx0783g.16.

Sande, N., and M. H. Samushonga. 2020. "African Pentecostal Ecclesiastical Practices and Cultural Adaption in a Changing World." Journal of the European Pentecostal Theological Association. https://doi.org/10.1080/18124461.2020.1714137.

Thiselton, A. C. 2015. Systematic Theology. Grand Rapids: William B. Eerdmans Publishing.

Zagano, P. 2012. Women in Ministry: Emerging Questions about the Diaconate. New York: Paulist Press.

Ziguras, C. 2004. Self-care Embodiment, Personal Autonomy and the Shaping of Health Consciousness. London: Routledge. https://doi.org/10.4324/9780203633977. 